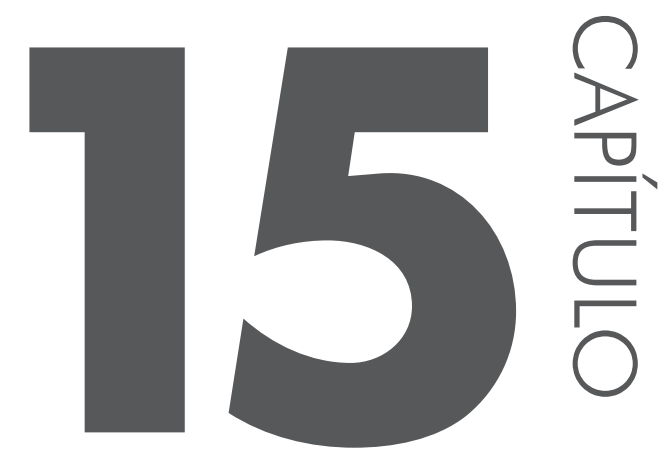

\title{
O reino do Mbalundo: uma análise sobre a questão da sucessão, autoridade e hierarquia
}

\section{Marino Leopoldo Sungo}

Universidade José Eduardo dos Santos

\section{Introdução}

Este capítulo abordará a sucessão, autoridade e hierarquia no reino do Mbalundo, uma instituição consuetudinária localizada no centro-sul de Angola. A abordagem se fará com base nas tradições sucessórias que fazem interagir território, cultura, história, língua e simbologias. Esse conjunto de aspetos concorrem para que o reino seja concebido como uma instituição política com reconhecida liderança perante o Estado nacional angolano da atualidade. E a própria memória social do reino reafirma em suas diversas versões que sempre foi assim, pois, mesmo antes da chegada de colonizadores vindos de Portugal, a noção de reino era praticada, e mesmo durante as guerras coloniais, o reino era reconhecido como organização local e regional, embora, nos processos guerreiros que se sucederam, tenha assumido diversas conceções e regimentos. Sua base consuetudinária, centrada na memória oral, contudo, promoveu a manutenção do projeto de integração dessas populações locais em torno de uma ideia de união a partir de um líder soberano (soma inene ${ }^{59}$ ) e uma organização defensiva e de integração regional. A

59 Soma inene: rei, autoridade máxima do reino, soberano. Quando a sílaba "so" for posposta ao prefixo "lo", estamos diante de uma pluralização da expressão, e para o caso a escrita seria "losoma inene" ou "olosoma inene" dependendo do contexto. 
ideia do "local" que norteia esta análise dialoga com a defendida por Appadurai, pois, de acordo com o autor "localidades são mundos de vida constituídos por associações relativamente estáveis, histórias relativamente conhecidas e compartilhadas e espaços e lugares reconhecíveis e coletivamente ocupados" (APPADURAI, 1997, p. 49). Estou ciente das implicações que esta concepção traz no processo de construção do Estado-nação, por sinal em vigor em Angola. Porém, entendo que é ao mesmo tempo um dos fundamentos da relação que o Estado nacional angolano atual, através do MPLA-governo ${ }^{60}$ que pretende garantir a sua soberania territorial, mantém com o reino.O trabalho de campo é indispensável para uma análise como esta, que privilegia informações tomadas in loco, até porque, e de acordo com Matta, "é o modo característico de coleta de novos dados para a reflexão teórica, ou como gostavam de colocar certos estudiosos de visão mais empirista, como o laboratório do antropólogo social" (MATTA, 1981, p. 143). Realizei uma observação participante - face to face - considerada como a marca disciplinar da antropologia, na medida em que estabelece uma convivência direta entre o pesquisador e o sujeito de pesquisa. A respeito desse método e do trabalho de campo em Antropologia, James Clifford diz que

a antropologia moderna - uma ciência do homem intimamente relacionada à descrição cultural - pressupõe uma atitude irônica de observação participante. Ao profissionalizar o trabalho de campo, a Antropologia transformou uma situação amplamente difundida num método científico (CLIFFORD, 2002, p. 101).

Nesse sentido, as tradições orais e/ou narrativas tornaram possível a escrita deste capítulo. Ou seja, fui ao campo ciente de que boa parte de meus sujeitos de pesquisa se servem por e simplesmente da oralidade para perpetuar seus hábitos e costumes, que, quando praticados, unem o passado ao presente. Aliás, nós, africanos, somos defensores da palavra, para nós a palavra tem peso, reconhecemos a importância que a fala tem na comunicação diária, porém, essa importância não é vista só nesse prisma fundamentalmente linguístico e comunicativo, na medida em que também percebemos a fala como um meio de preservação da sabedoria dos nossos ancestrais em que os protagonistas são os nossos anciãos. Por essa razão, sempre tive em mente que me serviria fundamentalmente das narrativas

60 MPLA-governo. É a expressão que aqui utilizo para exteriorizar a ideia de sistema de partido dominante ou de que o MPLA é o partido no poder, fruto das eleições gerais realizadas em 2012. O regime político vigente em Angola é o presidencialismo, em que o presidente da República é igualmente chefe do Governo, que tem ainda poderes legislativos. Por essa razão, cabe a ele eleger e nomear os dezoito governadores provinciais, que executarão suas diretrizes. Em suma, o partido vencedor constitui o governo de Angola. 
para compreender certas realidades através da história oral. Porém, também estive sempre ciente dos cuidados que, enquanto utente desse método de pesquisa, devia ter, o que me levou a desenvolver uma certa capacidade de crivo. Aliás, a respeito disto, Vansina postulou que "as tradições desconcentram o historiador contemporâneo - imerso em tão grande número de evidências escritas, vendo-se obrigado, por isso, a desenvolver técnicas de leitura rápida" (VANSINA apud KI-ZERBO, 2011, p. 140). Na mesma senda, porém referenciando Fu Kiau, Vansina postulou que

é ingenuidade ler um texto oral uma ou duas vezes e supor que já compreendemos”. Ele deve ser estudado, decorado e digerido internamente, como um poema, e cuidadosamente examinado para que se possam apreender seus muitos significados. (VANSINA apud KI-ZERBO, 2011, p. 140).

Nesse sentido, e enquanto "antropólogo", só uma capacidade de interpretação (teoria interpretativa) das informações recebidas permite desvendar as lógicas imbricadas nessas narrativas.

Outrossim, é que este convívio com os sujeitos de pesquisa, ou a observação participante, me levou a uma apreensão dos fenômenos sociais, na medida em que permitiu-me fazer uso de três técnicas de coleta de dados que Cardoso chama de "etapas de apreensão dos fenômenos sociais: o olhar, o ouvir e o escrever" (OLIVEIRA, 2000, p. 18). Olhando e ouvindo disciplinadamente, pude exercitar minha percepção sobre o assunto, e, no escrever, exercitei minha compreensão de forma mais cabal. $\mathrm{O}$ uso dessas técnicas permitiu-me ainda constatar aspectos que para sua fundamentação me fizeram recorrer a certas categorias analíticas e perceber o que certos teóricos dizem sobre as mesmas, o que de certo modo ampliou as minhas buscas bibliográficas, como postulou Ilka Boaventura Leite: "dinâmicas sociais propiciam novas informações, olhares e conclusões que a cada momento desafiam o pesquisador a permanecer no campo, a rever os dados, a buscar novos documentos" (LEITE apud CARDOSO, 2008, p. 37).

Devo destacar também o papel dos métodos comparativo e analítico nessa análise. O comparativo permitiu-me separar por períodos os governos jurídico-administrativos que operaram e operam mais precisamente na circunscrição onde se localiza a atual sede do reino, compreender a forma como cada governo inseriu ou insere em seus esquemas governativos as autoridades consuetudinárias do reino, bem como perceber especificamente a organização política do reino dentro do mosaico das demais e atuais instituições consuetudinárias angolanas. Já a compreensão da operacionalidade desses sistemas, e a descrição das relações de dependência recíproca, é consequência do uso do método analítico. Ou seja, a organização política do reino foi analisada sob o ponto de vista diacrônico e sincrônico. 
Assim sendo, entendo que, para se compreender a organização política do reino e o descrever como uma instituição soberana do ponto de vista consuetudinário, bem como a descrição da relação que o mesmo mantém com as instituições jurídico-administrativas, torna-se indispensável o cruzamento do método comparativo e analítico, isso é, comparar os diversos sistemas entre si, sujeitando cada um deles a uma análise sistemática.

Foi com base nisso que entendi o reino do Mbalundo como uma instituição consuetudinária angolana e que representa a forma de organização social, econômica e, sobretudo, político-cultural da etnia ovimbundu, considerada o maior grupo étnico de Angola, não só do ponto de vista geográfico, isso é, considerando a territorialidade abrangida, mas, também, reconhecendo a representatividade identitária dos ovimbundu no território nacional angolano atual, uma vez que as ferramentas das fronteiras étnicas existem e se articulam nas cabeças dos sujeitos.

\section{Espaço e território Mbalundo e os aspetos demográficos e socioeconômicos na atualidade.}

O reino abrange quatro províncias (Huambo, Bié, Benguela e parte da $\mathrm{Hu}-$ íla). Essa abrangência territorial pode ser explicada levando em consideração processos que fundamentalmente aconteceram no período colonial, pois, nessa altura, mais precisamente na década de 1960 até princípios dos anos de 1970, a administração colonial portuguesa implementou em Angola e, nesse caso, no planalto central, um sistema denominado "aldeias concentradas", que consistia em unir no mesmo espaço duas ou mais aldeias que apresentassem certos aspetos culturais como a pertença religiosa e outros processos de sociabilidade semelhantes. Esses locais para a concentração dessas populações eram escolhidos pelas autoridades coloniais portuguesas, e os critérios para tais escolhas levavam em consideração a necessidade de garantir o sistema e os apetites coloniais. Esse processo terá provocado, em meu entender, duas situações que a seguir descrevo.

A primeira é que desestruturou a micro organização econômica e política das populações, pois tais critérios, por um lado, não consideravam as exigências da agricultura de adaptação que por necessidades, entre outras, migratórias, os ovimbundu praticavam, e, por outro, desautorizavam as autoridades consuetudinárias de tais aldeias.

A segunda é que esse sistema de aldeias concentradas originou uma ampla organização político-cultural que hoje é conhecida como etnia ovimbundu e cujo maior expoente em termos institucionais é o reino do Mbalundo. Ou seja, ao aglomerarem no mesmo local populações oriundas de aldeias diferentes, criaram condições que lentamente incitaram a formação de uma identidade comum ou de um sentido de pertença mais abrangente para as populações do planalto 
central de Angola, e não só, pois aproximou os ovimbundu que, do ponto de vista geográfico, se encontravam distantes uns dos outros, bem como propiciou a "umbundização", ${ }^{61}$ fundamentalmente linguística, de alguns povos vizinhos que, antes de aglomerados, apresentavam determinadas características de certo modo diferentes dos ovimbundu. Um exemplo dessa umbundização seriam os hoje ovimbundu de Kakonda, uma região da província da Huíla.O reino do Mbalundo tem a sua sede situada no município e comuna que até 1896 se denominou Katapi, pois acredita-se que foi a partir de 1896 aproximadamente, após o capitão Justino Teixeira da Silva ter derrotado o soma inene Numa II, sucedido pelo soberano Ekuikui II, que a região ascendeu à categoria de vila pelo decreto-lei ${ }^{\circ}$ 54 do boletim oficial $n^{\circ} 1$ de 1986, passando a chamar-se Vila Teixeira da Silva, e, com o alcance da independência nacional, fundamentalmente política, o Estado nacional angolano, considerando os fundamentos históricos e culturais locais, legitimou a designação atual (Bailundo). Bailundo é um dos onze municípios da província do Huambo, região centro-sul de Angola, que dista aproximadamente $75 \mathrm{~km}$ da cidade capital (Huambo). É limitado a norte pelo município do Mungo e Andulo, a sul pelos municípios de Tchicala Tcholoanga e Huambo, a leste pelos municípios do Cunhinga, Catchiungo e Chinguar, e a oeste pelo município do Londuimbale. O município conta com cinco comunas, nomeadamente Bailundo, Bimbe, Hengue, Lunge e Luvemba, 573 aldeias e 79 povoações, ocupando uma extensão territorial de aproximadamente $7.075 \mathrm{~km}^{2}$.

O município do Bailundo é atravessado por várias cadeias montanhosas das quais se destacam as de Lumbanganda, Chilono, Nity e o morro de Halavala, onde jazem os restos mortais de Katiavala I (o fundador do reino no século XVI) e Ekuikui II, símbolos da resistência anticolonial na região do planalto central.

Do ponto de vista demográfico, o município do Bailundo possui uma população estimada em 284 mil habitantes (segundo os resultados do último censo publicados em junho de 2014). Diariamente, o mesmo apresenta uma média de natalidade a rondar a casa dos 35 nados, porém, para se ter uma perspetiva numérica atual e mais aproximada da população, é necessário que se adicione a esse valor o número de nados diários, de junho de 2014 ao presente momento. Paralelamente a isso, salientar que esse valor de nados diários é institucional (nascidos em hospitais, centros de saúde), o que quer dizer que se ainda adicionarmos a esse número os partos caseiros, certamente que poderá aproximar-se a casa dos sessenta nados por dia. Dessa feita, julgamos estar diante de uma taxa de natalidade alta.

61 Umbundização: é um termo ou expressão que aqui utilizo para exprimir ou explicar o processo de ensino e aprendizagem da cultura ovimbundu. 
Em sua economia, a população é majoritariamente camponesa, e tem como base do sustento a prática agrícola, atividade facilitada por essa região dispor de um vasto recurso hídrico, pois é banhada por onze rios, nomeadamente Keve, Cutato, Cupassi, Cuvira, Cungamua, Curindi, Culele, Cucai, Kusso, Luvulu e Chitonga, e de um clima predominantemente tropical e úmido. Dito de outra forma, as condições naturais de que a região dispõe fundamentam a adesão da população à produção agrícola e fazem dessa prática o seu principal sustento, produzindo com abundância a batata-doce e rena, feijão e milho. Este último é majoritariamente triturado para a obtenção da farinha com a qual confecionam o pirão, um dos pratos típicos da região. Por essa razão, as vastas fazendas antes abandonadas por imperativos da guerra civil, com o calar das armas, têm vindo a retomar gradualmente as suas funções na produção de hortícolas, tubérculos e verduras. A criação em grande escala, de gado bovino e caprino, aos poucos, vai dando vida ao mercado local. De acordo com Irineu Cândido Leonardo Sacaála, atual administrador do município do Bailundo: "No campo agrícola nós controlamos 7 fazendas e destas nós podemos destacar 4 operacionais ou funcionais onde apenas uma é agropecuária e as demais são reservadas a atividade agrícola" (entrevista realizada no seu gabinete em março de 2015).

Ainda sobre o setor econômico, o Bailundo tem vindo a conhecer progressos sucessivos, pois a ele se deslocam empreendedores não só angolanos de nacionalidade, como também oriundos de outros pontos do mundo, com maior destaque para os vietnamitas e chineses. Enfim, entendo que o crescimento do comércio e a vinda de elementos externos ao município com fins diversos, onde se pode mencionar, por exemplo, o de visita à ombala do reino, ${ }^{62}$ implicou o surgimento de várias agências bancárias no município, de indústrias, embora ligeiras (moageira, cavalarias), bem como o alargamento do setor da hotelaria e turismo. Esse olhar sobre a vida econômica do município foi comprovado pelo administrador municipal do Bailundo, pois, segundo o mesmo, "do ponto de vista econômico, o nosso município tem estado a evidenciar-se mais no ramo do comércio, um bom número de comerciantes embora com condições precárias, têm vindo a desenvolver esta atividade, tanto mais que em cada ombala já existe um boteco que pelo menos consegue dar aquilo que a população precisa, estamos a falar de óleo, açúcar, sabão, sal, conservas, quer dizer, estamos a falar daquelas necessidades básicas.

62 Como exemplo se pode mencionar a visita efetuada à ombala em fevereiro de 2015, por parte de Taata Katuvanjesi (Walmir Damasceno), coordenador nacional do Instituto Latino Americano de Tradições Afro Bantu (ILABANTU), acompanhado entre outros da senhora Judith Luacute, representante dessa organização em Angola. A mesma teve como objetivo efetuar presencialmente um convite ao rei Ekuikui V para se deslocar no território brasileiro, respondendo, assim, ao pedido de brasileiros descendentes de angolanos escravizados oriundos de Benguela. 
Nos outros ramos contamos com 4 agências bancárias, nomeadamente, o Banco de Poupança e Crédito (BPC), Banco Sol, Banco de Fomento Angola (BFA) e o Banco Bic Angola (BIC). A rede hoteleira, ainda não é a mais desejada, mas contamos neste momento com três hospedarias e um hotel em construção. No setor industrial, contamos ainda com aquela indústria considerada ligeira, estamos a falar de moageira, cavalarias e em número reduzido" (entrevista realizada no seu gabinete em março de 2015).

\section{A ombala yo Mbalundo}

Ombala yo Mbalundo é o palácio do reino, o local onde está construída a residência oficial do soma inene e dos losoma vionduko ${ }^{63}$ respectivamente, e encontra-se localizada na vila do município do Bailundo. Seus habitantes, para além de partilharem o mesmo espaço, servem-se de hábitos e costumes comuns. Porém, a ombala é também usada para designar o bairro onde especificamente está implantado o palácio, e observando a localização das moradias no interior da ombala, bem como o material pelas quais são atualmente construídas tais moradias - umas com técnicas de arquitetura "moderna" (Figura 13.1), ${ }^{64}$ e outras com técnicas de arquitetura vernácula (Figura 13.2) - , percebi que elas podem ser ao mesmo tempo usadas como indicadores da estratificação social, econômica e fundamentalmente política dos ovimbundu locais. As construídas, fazendo recurso à arquitetura "moderna", pertencem ao soma inene e aos losoma vionduko, e encontram-se localizadas no centro da ombala, ao passo que as habitações da maioria dos ovimbundu comuns são construídas com as técnicas de arquitetura vernácula, e encontram-se situadas nas periferias da ombala.

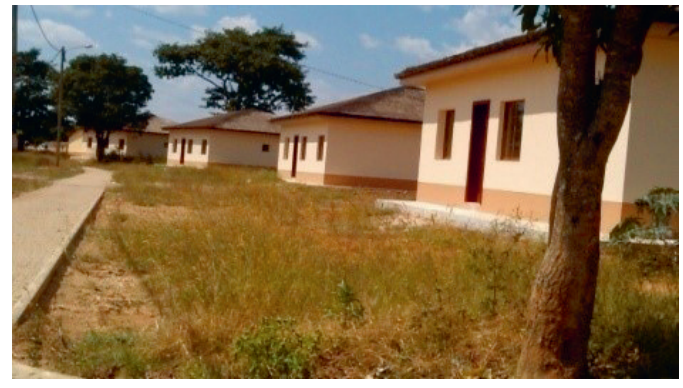

Figura 15.1 - Residências protocolares

63 Losoma vionduko ou olosoma vionduko: autoridades de nomes. Conjunto de autoridades do reino que constituem a corte do soma inene.

64 Essas moradias foram construídas de acordo com as políticas do MPLA-governo, de melhorar as instituições consuetudinárias angolanas, como forma de reconhecimento ao trabalho que estes desenvolvem em suas localidades, e o projeto-piloto, desenvolveu-se na ombala yo Mbalundo. 


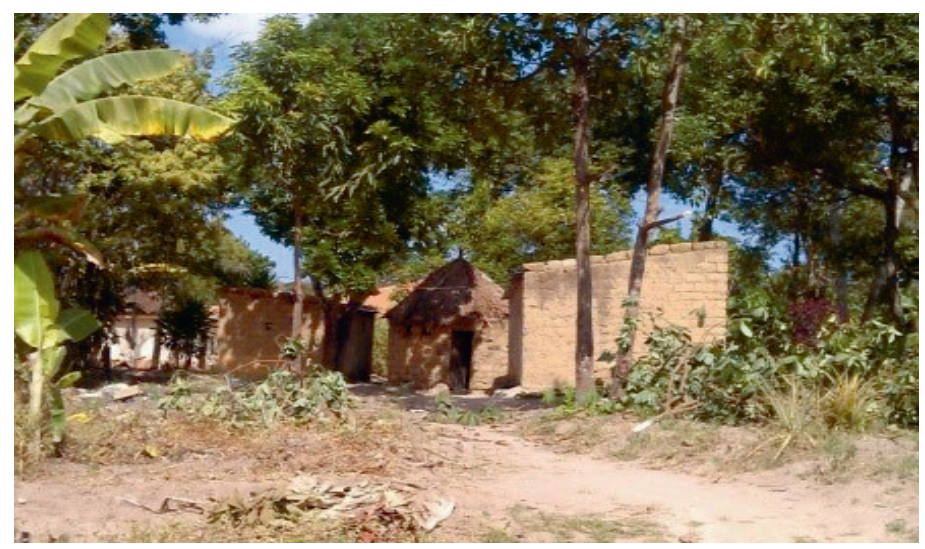

Figura 15.2 - Residências singulares

O dia-a-dia dos moradores nos arredores da ombala, desde o amanhecer até ao pôr-do-sol, é caracterizado por movimentos de adultos indo a busca do sustento, e de crianças, adolescentes e uma dúzia bastante reduzida de jovens, em direção à escola. Devo ressaltar que as aulas são administradas em língua portuguesa.

As refeições são infalíveis. As matinais são feitas sem um critério em termos do que se comer, porém, acontecem em torno das 6, 7 e 8 horas, e caracterizam-se pelo uso frequente de produtos naturais como a mandioca, a abóbora, o milho, a batata-doce e o pirão (funje) de milho, que é quase sempre acompanhado de verduras, como folhas de mandioqueira, de feijoeiro, ramas de batateira e de abóbora localmente chamada de lombi. Nos almoços, dificilmente essa comunidade serve-se de outro alimento que não seja o pirão e com os acompanhantes habituais supracitados e, raramente, acontecem em coletivo, pois que os pais, ao saírem no período matinal, em condições normais, apenas retornam para suas casas no período da tarde; logo, almoçam fora, geralmente nas lavras. Os jantares, diferentemente dos pequenos almoços e almoços, são feitos na presença de todos os membros da família, e os responsáveis de casa aproveitam o momento para transmitir em umbundu ou português os valores que incitam a unidade entre eles e com externos. E o pirão com os habituais acompanhantes constitui genericamente o cardápio, mas com um porém, o uso de uma bebida produzida localmente chamada kisangua, ${ }^{65}$ conforme as Figuras 13.3 e 13.4.

65 Kissangua: é uma bebida caseira e típica dos ovimbundu. Ela é feita de osovo (milho não triturado) ou cascas de ananás, bundi e água. Depois de preparados, conserva-se num recipiente até azedar, pois só depois de atingir esse estado estará devidamente pronta para o consumo. 


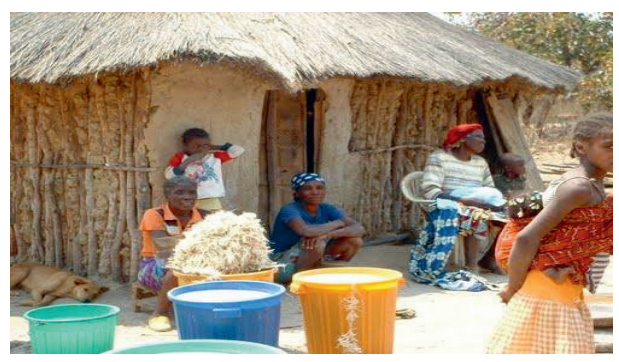

Figura 15.3 - Kisangua sendo preparada. Fonte: Agência Angola Press.

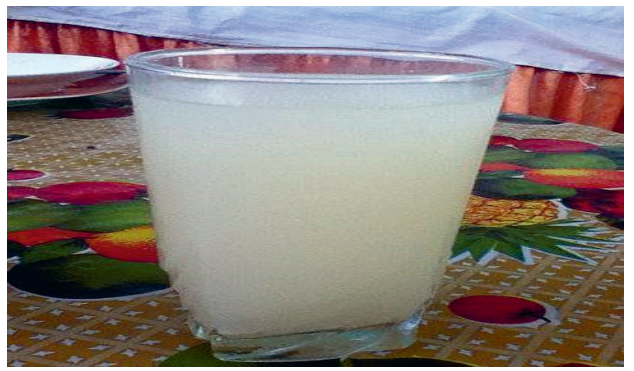

Figura 15.4 - Kisangua já pronta. Fonte: Agência Angola Press.

No centro da ombala, os movimentos são agitados nos dias em que no local se realiza julgamentos, pois esse processo, para além da presença obrigatória das partes conflituantes, que podem ser munícipes internos ou externos, acarreta para o local também pesquisadores, jornalistas e outros agentes sociais. O contrário acontece em dias em que não se realiza julgamentos ou quaisquer outras atividades na ombala, pois nota-se um ambiente bastante calmo, onde apenas se pode ver a movimentação daqueles constituintes da corte com a função específica de manter a higiene e segurança do local, bem como de crianças que aproveitam da sombra das árvores do local para diversões.

Os jogos lúdicos tomam conta da camada juvenil durante uma parte da noite, ao passo que os adultos, visando a retemperar as energias para as jornadas do dia seguinte, dormem geralmente após acompanharem o jornal da noite pela TV ou rádio, que vai ao ar às $20 \mathrm{~h}$, pontualmente.

\section{O processo de sucessão no reino}

Segundo a tradição oral, o soberano ovimbundu só deveria ser substituído após a sua morte. Morte que, quando por doença, não pode acontecer na ombala ou palácio. De acordo com Ekuikui V, 
temos um local próprio no interior da ombala onde a corte leva o rei quando os espíritos comunicarem que ele já vai morrer. E, depois do rei morrer, a população não pode saber logo, a corte só vai comunicar a morte do rei depois de uma semana, porque temos passos para cumprir antes de anunciar, um deles é a divisão entre a cabeça e o corpo do rei, porque nós não enterramos a cabeça, mas, sim, o corpo, a cabeça fica conservada no nosso atambo ${ }^{66} \mathrm{e}$ o corpo é sepultado lá nos akokotos. ${ }^{67} \mathrm{E}$ neste momento a corte já sabe quem é o parente que vai substituir, e não é qualquer parente, existem regras que cumprimos, tem que ser um sobrinho da parte materna ou neto como eu. E no dia da entronização do novo rei, a corte vai até em casa dele, lhe amarram um lenço branco nos olhos e lhe trazem lá na ombala, e aí aplicamos todos os nossos rituais de entronização, na presença da população e parentes, de representantes do Estado, líderes religiosos e partidários. Aí o tio do futuro rei terá a missão de explicar bem as origens do futuro rei a todos e se alguém achar que ele não pode ser, porque não é legítimo, deve reclamar, mas isto também não vai acontecer porque a corte não escolhe à toa. (Entrevista concedida em sua residência / Março de 2015).

Este e outros pronunciamentos do soma inene levaram-me a consolidar a ideia de que o reino é uma organização consuetudinária com a estrutura ou organização política assente no parentesco. Acredita-se que, no reino, o sistema de sucessão seja matrilinear, determinando assim que o processo aconteça respeitando a linha uterina, ${ }^{68}$ onde o privilégio recai ao sobrinho materno e, na ausência deste, ao neto, porém, observando sempre o direito de primogenitura, ${ }^{69}$ ou seja, num sistema similar a este e, de acordo com padre Altuna,

as heranças passam pelo ramo uterino; os filhos não herdam diretamente do pai. A herança do tio materno passa para o sobrinho primogénito de sua irmã uterina mais velha, ou para o seu irmão uterino, e as chefias para o sobrinho do tio falecido, o primogénito da irmã uterina mais velha. Este sobrinho tem de certeza o sangue nobre que corria no chefe (ALTUNA, 2014, p. 110).

Porém, as mesmas e outras fontes me levam a um entendimento adicional a esse, isso é, que considera a existência de um sistema bilinear, e, olhando para aquela que é a característica do continente africano, julgo que isso se enquadra, pois, de acordo com Dozon,

66 Atambo: expressão em língua umbundu que designa o local por onde jazem os crânios dos soberanos do reino. Esse local é considerado um santuário tradicional.

67 Akokotos: expressão na língua umbundu que designa cemitério dos soberanos do reino.

68 Uterina: parente pelo lado materno (BURGUIÉRE, 1998, p. 327).

69 Direito de primogenitura: fórmula do direito que consiste em dar sistematicamente preferência ao primogênito em detrimento dos irmãos mais novos. Geralmente trata-se do primogênito varão (BURGUIÉRE, 1998, p. 324). 
Os sistemas familiares africanos caracterizam-se pela diversidade dos seus modos de filiação - patrilinear, matrilinear ou bilinear -, encontrando-se cada indivíduo incluído numa trama que o liga a todos os outros por conexões genealógicas: pertence ou ao grupo do pai ou ao da mãe (ou a ambos, segundo diversas modalidades). (DOZON, 1998, apud BURGUIÉRE et al., p. 266).

Desde a fundação do reino até os dias atuais, a sucessão orientou-se por quatro regras que foram aplicadas em fases subsequentes, realçando, porém, que, em todas elas, o fator parentesco e as competências dos candidatos (entre outros, o conhecimento da cultura local, espírito de liderança) eram consideradas. Assim sendo, a primeira fase seria aquela em que, para a sucessão ao trono, considerava-se a perspectiva patrilinear, e como exemplo poderíamos citar os lossoma inene Chingui II e Ekuikui I, que foram filhos de Chingui I, assim como o soma inene Ekuikui II, que foi filho do soma inene Chivukuvuku. Posteriormente, e como consequência de certas dúvidas sobre a real paternidade dos filhos, outra decisão foi tomada, que aqui chamaria de segunda fase, isso é, aquela onde a sucessão seria matrilinear, considerando-se para o efeito o tio materno como pai. Nessa perspectiva, o privilégio recai ao sobrinho primogênito (filho da irmã primogênita), ou ao neto também primogênito. Com o passar do tempo, a administração colonial portuguesa, fruto de uma contenda entre sobrinhos e filhos, decidiu inverter o quadro, legitimando os filhos em detrimento dos sobrinhos, levando assim o reino a uma terceira fase, onde a sucessão passou a servir-se de duas matrizes, isso é, levando em consideração em determinados momentos a perspectiva matrilinear, e noutros, a patrilinear, ou seja, estamos diante de um sistema bilinear. A última e quarta fase é a da perspectiva atual, isso é, um retorno à segunda perspectiva, a da sucessão segundo a matriz matrilinear.

Outro aspecto, que julgo ser indispensável ao processo de sucessão ao trono no reino, é a problemática do casamento poligâmico, pois, entre outras, implicações econômicas e sobretudo políticas levavam os losoma inene a adotarem essa modalidade de casamento. Entendo que, em linhas gerais, nas sociedades bantu, o número de esposas, durante um bom tempo, categorizava política e economicamente os indivíduos, e, de acordo com padre Altuna,

os filhos numerosos outorgam autoridade, influência, respeito, admiração, inveja e veneração patriarcal. Os chefes consolidam o seu poder por meio de alianças matrimoniais com outros grupos ou com membros do seu grupo, que assim ficam incluídos no círculo estreito da sua amizade e influência. Nasce a poligamia com finalidade política. O chefe, para além disso, deve gerar muitos filhos para assegurar e potenciar a vitalidade do seu grupo. É o melhor modo de expressar e justificar a sua posição na pirâmide vital. (IBIDEM, 2014, p. 345). 
Esse indicador, que julgo estar na origem de várias contendas sobre a legitimidade no processo de sucessão, permite compreender e explicar a crença local sobre a existência de várias linhagens de soberanos no reino e, por fim, descrever o mesmo como a causa da revitalização de uma linhagem. De acordo com Ekuikui $\mathrm{V}$,

após a morte do rei, os sobas grandes da região e a corte reúnem para escolherem o sucessor e eles se perguntam: aqui já passou a linhagem de Katiavala, já passou a linhagem do rei Ekuikui, já passou a linhagem de Utondossi, mas nesses ramos quem pode substituir o lugar? Então eles vão vendo em todos os ramos e depois escolhem um fulano. (Entrevista concedida em sua casa / Março de 2015).

Desta feita, a escolha pode recair ao parente de um antigo soberano, isto é, que vários reinados sucederam após a sua morte e cujos escolhidos eram parentes de outros, o que poderá por um lado criar um ambiente de insatisfação e eventuais reclamações dos membros pertencentes às demais linhagens, e, por outro lado, propiciar uma revitalização da linhagem escolhida e do próprio sistema. Um dos exemplos de que a escolha varia e pode revitalizar uma certa linhagem poderia ser o caso dos Ekuikuis. Hoje são contabilizados no reino 36 soberanos, porém, desde 1780, ano em que a memória considera como o do reinado de Ekuikui I, até ao presente momento (2016), só estamos no quinto dos Ekuikuis. A seguir, tento demonstrar a partir de uma simplificada ${ }^{70}$ árvore genealógica o sistema de sucessão, descrito como exemplo.

70 Simplificada pela inexistência de dados escritos - por sinal, nem com a memória ou narrativas locais foi possível tê-los. 


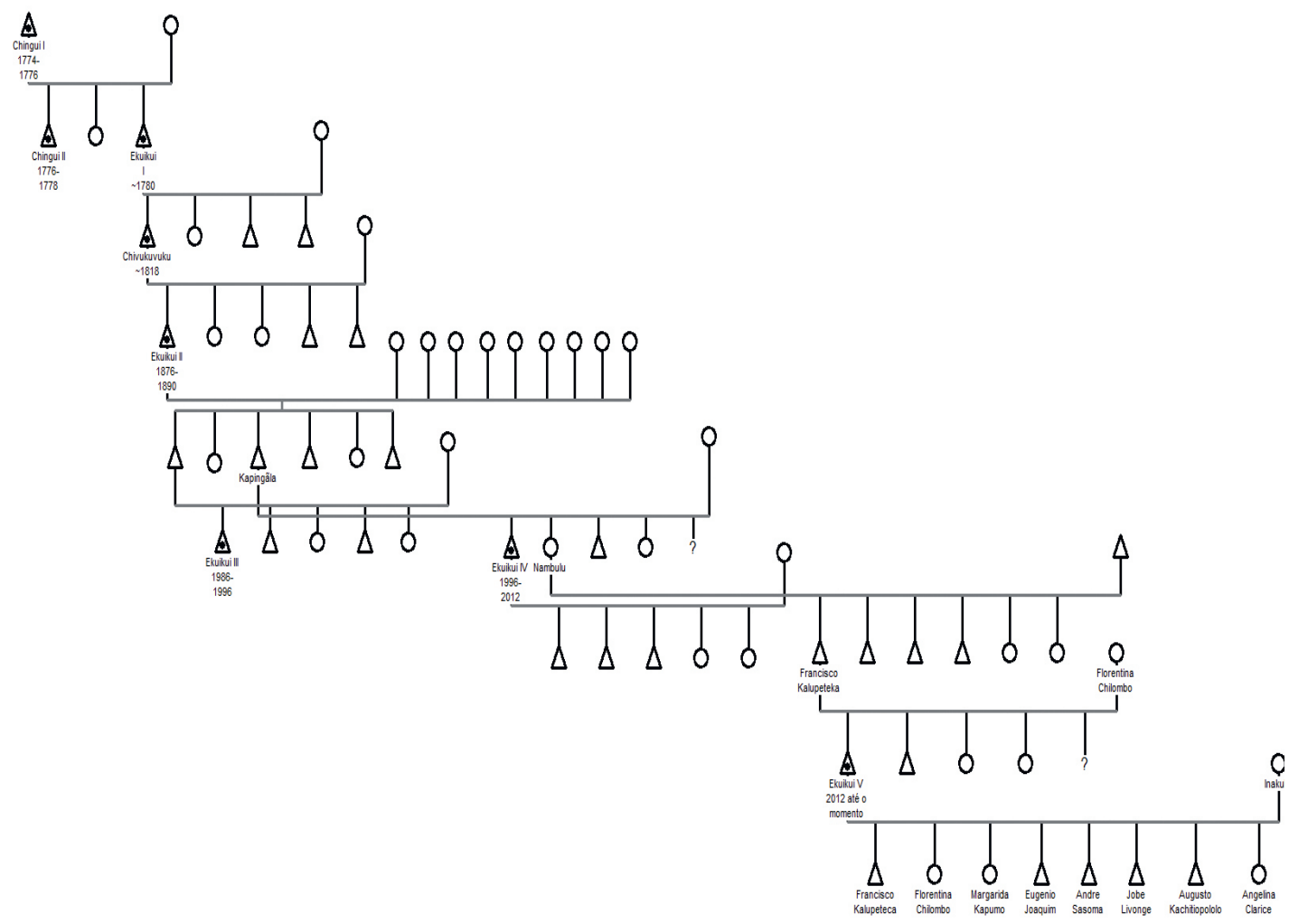

Figura 15.5 - Árvore genealógica dos Ekuikuis. Fonte: Autoria pessoal.

Legenda: • = Soberanos ou reis; ? e = Imprecisão.

A imagem representa um esquema sucessório do reino do Mbalundo, porém, apenas da linhagem dos Ekuikuis, pois o meu principal interlocutor, o soma inene Ekuikui V, é descendente da mesma, e proporcionou-me algumas informações que me permitiram montar um quadro dessa tradição sucessória. A mesma apresenta uma certa imprecisão quanto ao número de filhos, de esposas, bem como ao período de reinado que aparece referido por baixo do nome de cada um dos soberanos representados, mas tem como objetivo permitir-nos olhar com mais detalhe esquemático para o caso mais recente. Quanto ao número de esposas, constou-me ainda que o soma inene Ekuikui II teve sessenta esposas, porém, atendendo às imprecisões, decidi representar apenas nove delas. Devo dizer também que bastava ter filhos com alguém para ser considerado(a) esposo(a), e daí o número elevadíssimo de esposas do soma inene Ekuikui II. 


\title{
As influências externas no processo de sucessão
}

O Mbalundo foi e é alvo de interferências externas em determinados momentos e processos. A respeito disso, me servirei da antropologia dos encontros coloniais para refletir sobre as interferências no processo de sucessão correspondentes ao período do colonialismo português, na medida em que, de acordo com Caldeira,

\begin{abstract}
a Antropologia dos encontros coloniais tende a explorar não só as relações de dominação e desigualdade entre os colonizadores ocidentais e os povos colonizados do terceiro mundo, mas a produção de situações e culturas específicas como resultados desses encontros. Focalizam-se, portanto, novas formas sociais e culturais produzidas por transformações e reelaborações de elementos tomados tanto das culturas capitalistas ocidentais, quanto das culturas "nativas". (CALDEIRA, 1989, p. 5).
\end{abstract}

Nessa senda, a doutora e escritora Neto, para além de recomendar a leitura integral do Decreto-Lei 23.229, de dezembro de 1933, postulou as intervenções feitas pela administração colonial e, nesse sentido, afirmou que "a sucessão seria feita pelos usos e costumes locais, mas o Governo tinha direito de escolher quando o herdeiro não convinha à administração - Artigo 96 " (NETO apud MAT, ${ }^{71}$ 2004, p. 183). Um outro exemplo de intervenção da administração colonial portuguesa nesse processo, e que esteve na causa da transição da segunda para a terceira fase dos princípios que moldam a sucessão no reino, foi-me narrada pelo soma inene Ekuikui V, pois, de acordo com o mesmo,

antigamente, o pai era o tio irmão da mãe, não era o pai biológico, mesmo até hoje no Lubango, isto ainda funciona, quando o tio morre a herança passa para os sobrinhos, mas nós aqui quem atrapalhou este sistema foi o colono português. Certa vez, o tio e o sobrinho trabalhavam e tiveram uma fazenda de café, depois da morte do tio, o filho fez confusão, disse que esta fazenda é minha, ele nunca passou lá na plantação, mas quando o tio morre, o pai morre, ele disse que isto me pertence, isto é meu, o sobrinho que estava ali a perder o seu tempo junto o tio disse que não, isto me pertence porque eu é que sou o filho verdadeiro porque a irmã do seu pai é que me teve, você não sei se veio da onde. Mas quando foram a justiça no tribunal jurídico, o branco perguntou, mas quem é mesmo o filho, o filho direto? E ele disse que o filho sou eu, e eles disseram, então a fazenda é sua e você também vai procurar o seu pai. Então a partir daquela data, o pai biológico passou a ser mesmo o pai, é mesmo o que teve o filho. (entrevista concedida em sua casa / Abril de 2015).

Essa narrativa espelha uma mudança imposta na lógica de sucessão nativa.

71 MAT: Ministério da Administração do Território. 
$\mathrm{Na}$ atualidade, o Estado nacional angolano aconselha, orienta e controla determinadas atividades das autoridades locais, bem como avalia o grau de cumprimento das mesmas, pois, de acordo com administrador municipal Irineu Cândido Leonardo Sacaála,

bem, nós a nível da administração temos adotado políticas de modos que toda gente funcione. Ora, é preciso ter em conta que as autoridades tradicionais têm um subsídio mensal dado pelo governo, então este subsídio não tem que ser dado só por dar, portanto tem que se lhes exigir, ora, nesses encontros que temos tido com elas, nós manifestamos aquilo que precisamos. Portanto há muita coisa que as autoridades tradicionais têm que fazer, vamos falar do aspeto higiennico das aldeias, o ordenamento de construções e controlo da produção agrícola, o controlo dos partidos políticos, quer dizer, em suma, todas estas são tarefas específicas que as nossas autoridades tradicionais devem desenvolver lá nas suas localidades em que nos representam, portanto, elas têm atividades específicas, independentemente daquelas atividades costumeiras e nisso reside o nosso grande intercâmbio com as autoridades tradicionais, quer dizer, elas exercem essas atividades e nós vamos avaliando o grau de cumprimento em função das suas prestações de contas. (entrevista concedida, no seu gabinete / Março de 2015).

Entendo que esse diálogo abre portas para que certas interferências se façam sentir, visando a fortalecer a aproximação entre o reino e o MPLA-governo. Desta feita e se solicitado, julgo que sugerir para que a escolha do soma inene recaia em alguém que defenda as ideias do partido-governo pode ser um dos pressupostos para esse fortalecimento, e também porque como soberano, o soma inene poderá influenciar de certo modo na escolha dos demais losoma no reino. Um dos exemplos dessa reflexão, e de acordo com Florêncio, é que, "na comuna de Lunge, e por iniciativa do partido MPLA, foi introduzida nas aldeias uma subdivisão em bairros, ou zonas. Cada uma dessas zonas é agora igualmente controlada por um sekulu vitito ${ }^{72}$ (FLORÊNCIO, 2015, p. 5). E essas interferências terão acontecido também em certos períodos de gestão da região pela Unita. O episódio seguinte espelha essa problemática.Refiro-me à disputa ao trono ocorrida entre os losoma inene Utondossi II e Ekuikui IV. Tudo começou com a morte do soma inene Manuel da Costa (Ekuikui III), em 1996, num momento em que o município do Bailundo encontrava-se sob tutela das forças militares da Unita. Havendo necessidade de substituir-se o então soma inene, o eleito foi um dos sobrinhos, Jeremias Lussati, entronizado com o epíteto de Utondossi II. Em 1994, Augusto Kachitiopololo (Ekuikui IV) exercia ainda as funções de soma da ombala de Chijamba, na comuna de Luvemba, porém, com a ocupação da região pelas forças da Unita,

72 Sekulu vitito: adjunto do sekulo. 
teve que migrar para Benguela (onde se encontrava em condições de refúgio o governo da província do Huambo) e, posteriormente, foi para Luanda responder a um convite do presidente da República e do MPLA, tendo sido nomeado membro do Comitê Central do MPLA. Nessa altura, o reino se encontrava ainda sob o comando do soberano Utondossi II, que reinou até 1999, ano em que as Forças Armadas Angolanas (FAA) recuperaram o Bailundo das mãos das forças da Unita, originando a fuga de Utondossi II e parte de seu elenco de afetos à Unita.

Com o calar das armas e o consequente fim da guerra civil (2002), Ekuikui IV regressou ao Bailundo e assumiu a soberania do reino, fato que terá causado tumultos por parte daqueles que, a exemplo de Utondossi II, eram militantes da Unita. De acordo com Florêncio,

esta situação levanta uma certa celeuma, surda pode dizer-se, entre uma parte da população do município e uma parte da estrutura de poder tradicional, olosoma e olosekulu, afetos ao partido UNITA, e entre os ativistas desta mesma força política, que não atribuem legitimidade ao atual soma inene Ekuikui IV, e que defendem que se trata de uma imposição do Estado-MPLA, quer por ele ser membro do Comitê Central do partido no poder, quer para reforçar o controlo do partido sobre as autoridades tradicionais do reino. Esta situação agravou-se substancialmente em 2005, porque o anterior soma inene, Utondossi II, regressou ao Bailundo e continuou a deter uma forte legitimidade, sobretudo para os sectores da população e das autoridades tradicionais afetas à UNITA. (IBIDEM, 2015, p. 26).

Porém, a intervenção do poder jurídico e administrativo legitimou o soma inene Ekuikui IV como soberano do reino, liderando os destinos do mesmo até a sua morte, contra o desejo de todos que alegavam este não pertencer à linhagem uterina do Ekuikui III, a exemplo de Utondossi II.

Esse episódio também demonstra que as autoridades consuetudinárias em geral seriam apartidárias e com a opção de se tornarem também partidárias, pois que, por um lado, enquanto autoridades consuetudinárias, a própria lei costumeira as proíbe de agirem como partidárias no exercício de suas funções. Por outro lado, enquanto cidadãos do Estado nacional angolano, a própria Constituição da República de Angola (C.R.A), em vigor e atuante no seu Artigo 55\%, relacionado com a liberdade de constituição de associações políticas e partidos políticos, no seu ponto 2 , permite que uma autoridade consuetudinariamente "considerada" apartidária possa ser um cidadão partidário, pois, de acordo com o mesmo "todo o cidadão tem o direito de participar em associações políticas e partidos políticos, nos termos da Constituição e da lei” (C.R.A, 2010, p. 21).

Irineu Cândido Leonardo Sacaála, administrador municipal do Bailundo, confirmou essa dupla realidade, pois, de acordo com o mesmo, 
o Reino é apartidário, as autoridades tradicionais são apartidárias, porém cada um como pessoa tem ou pode ter a sua filiação partidária. O correto é que, no exercício de suas atividades eles se apresentem como apartidários. Portanto, é preciso entender bem isso, eles lá na ombala, devem resolver os problemas da comunidade, independentemente das filiações partidárias ou religiosas. Nós enquanto órgãos do poder jurídico-administrativo olhamos para o problema apresentado e não para a pertença partidária e naquilo que podermos resolvemos, e, é exatamente assim que as autoridades tradicionais devem e têm feito. (entrevista concedida, no seu gabinete /Março de 2015).

Porém, entendo que a pertença partidária ou não de um candidato pode ser um aspecto a se ter em conta por parte do partido-governo ou por parte dos partidos da oposição, se solicitados a sugerirem no processo de sucessão ao trono no reino. Questionado sobre o assunto, Ekuikui V revelou-me que

antes de eu ser o soberano do reino e da etnia ovimbundu, eu já era de um partido, e se um dia, ou se outro partido ganhar as eleições já tem o rei deles escolhido, mas ele para ser rei, a corte também deve aceitar, porque se não aceitar, não vai ser soberano no reino e não vai entrar na nossa ombala, vai procurar e inventar outra ombala dele" (entrevista concedida em sua casa / Abril de 2015).

Entendida nesses moldes, diria que condições para que influências externas e, para o caso, político-partidárias se façam sentir na problemática da sucessão ao trono no reino, data de algum tempo, na medida em que as organizações consuetudinárias ou étnicas angolanas há muito que se encontram vinculadas aos movimentos políticos e partidários, contribuindo para o desenvolvimento de um trabalho de organização e conscientização de massas. A própria história reza-nos que tais organizações, como, por exemplo, as etnias bakongu, mbundu e ovimbundu, estiveram envolvidas em determinados processos de guerrilha contra o Império Colonial Português e, para tal, aliavam-se aos movimentos políticos anticoloniais, de maior sonância na respetiva região. Enfim, as circunstâncias ou situações difíceis a que eram submetidos os angolanos por parte da administração colonial portuguesa que tinha apenas a mente posta no alcance de seus fins, sem olhar aos meios, independentemente da região ou etnia em que estivessem colonizando, tornaram-se fortes razões para uma adesão massiva, e naturalmente clandestina, dos diversos povos colonizados aos movimentos anticoloniais e, particularmente falando, grande parte dos ovimbundu aliaram-se à Unita.

Por tudo isso, devo dizer que essas interferências podem afetar negativamente o desempenho das autoridades do reino, e, quanto a isso, Goulart afirma que "a cooptação das autoridades tradicionais pelos partidos no poder constitui como um obstáculo ao devido exercício de suas funções e também, ao avanço da democracia na região" (GOULART, 2012, p. 2). 
Todavia, devo ressaltar aqui os constantes encontros entre as autoridades no sentido de incentivar a necessidade de separarem o joio do trigo nas suas intervenções, enquanto atores partidários e apartidários ao mesmo tempo. Ressalto, também, o fato de existir a observância ou respeito pelos princípios consuetudinários que regem a problemática da sucessão no reino por parte do MPLA-governo. E, apesar dessas influências político-partidárias e outras que o processo de sucessão do reino terá sido alvo, entendo que a consciência étnica da população lhes permite diferenciar os soberanos que, no entender deles, ascenderam à categoria de soma inene, respeitando os princípios emanados pelos costumes locais, daqueles impostos em defesa de outros interesses.

\section{A legitimidade a partir figura soberana}

A descrição feita anteriormente sobre o processo de sucessão no reino demonstrou que o mesmo depende de uma hermenêutica própria que se deve compreender para que se possa responder a eventuais questionamentos desse mesmo processo. Muitos desses questionamentos poderão estar ligados à problemática da legitimidade, e, a título de exemplo, poderia levantar os seguintes: quando é que se estaria diante de um sucessor legítimo no reino? Quem lhe confere essa legitimidade?

Dessa feita, e de acordo com a filosofia ou hermenêutica local, é considerado atualmente sucessor legítimo todo aquele que ascender à categoria de soma inene do Mbalundo segundo os princípios consuetudinários que regem tal processo, anteriormente descritos.

A segunda questão poderia respondê-la, considerando três agentes que concorrerem nesse processo de legitimidade do sucessor, nomeadamente as autoridades consuetudinárias, a população e o Estado, e que concomitantemente constituem as três formas de legitimidade que qualquer sucessor deve merecer para que, a meu entender, se considere legítimo.

\section{a) Legitimidade consuetudinária}

Ela poderia ser chamada também de "adquirida", na medida em que os candidatos à sucessão já nascem legítimos, e atendendo ao fato de que a organização política do reino é assentada no parentesco, a família de onde se nasce é o primeiro pressuposto analítico do qual a corte se serve para efetuar a escolha do sucessor, que posteriormente será legitimado pela população e pelo Estado.

Depois de escolhido, a legitimidade do sucessor é outorgada do ponto de vista consuetudinário durante a entronização. Durante o processo, as autoridades consuetudinárias servem-se de todos os meios possíveis para testarem e confirma- 
rem a legitimidade adquirida do escolhido. Um dos testes é o fogo que se acende durante a entronização, pois, de acordo com o Ekuikui V,

\begin{abstract}
"nós temos as nossas formas de apanhar qualquer pessoa que quiser ser rei, porque as pessoas pensam que ser uma autoridade tradicional dá dinheiro, todos querem ser reis do Mbalundo, mas ai na nossa ombala não entra qualquer pessoa como rei, deve ser da linhagem, se a pessoa não for da linhagem, o nosso fósforo tradicional, não vai acender, na hora de matar o boi, ele foge, até tiro pode-se fazer para matar o animal, é uma confusão, que os mais velhos veem mesmo que este não é legítimo e não pode ser. Agora se é mesmo da linhagem isso tudo acontece normalmente" (entrevista concedida em sua casa / Abril de 2015).
\end{abstract}

Enfim, as autoridades consuetudinárias do reino julgo se servem de três aspetos analíticos para efetuarem a escolha do sucessor; nomeadamente, a naturalidade, a consanguinidade e o conhecimento que o mesmo tem em relação aos hábitos e costumes dos ovimbundu em geral e do reino em particular.

\title{
b) Legitimidade populacional
}

Atendendo à filosofia interna de que o soma inene é o primeiro representante dos ovimbundu, julgo que o consentimento dos representados em relação à escolha do futuro soberano feita pelas autoridades consuetudinárias é indispensável.

Esta legitimidade se poderia chamar também de atribuída, na medida em que, para além de suceder à escolha das autoridades consuetudinárias, ela opera diante de uma divisão de decisões por parte da população, isto é, uns confirmando e outros contestando, e em linhas gerais, não se servem da pertença familiar do já escolhido como pressuposto fundamental para legitimar.

Acredito que por se tratar de uma escolha com fundamentos internos, por um lado, a possibilidade de existirem contestantes dificilmente será nula. Por outro lado, julgo que um sucessor escolhido pelas autoridades consuetudinárias terá o parecer positivo de boa parte da população. Dessa feita, uma vez escolhido, o mínimo que poderá acontecer é a existência de uns ovimbundu a favor e outros contra por vários motivos, como eventuais dúvidas sobre a genealogia do escolhido, o fato de a escolha não ter recaído ao candidato mais próximo ou parente desses, fanatismo e ou por não confiarem nas capacidades ou competências do escolhido.

O soma inene é legitimado pela população durante a cerimônia de entronização, logo após o abate do bode castrado. O mesmo coloca o seu pé direito sobre o animal abatido, e em seguida passa a citar um conjunto de nomes. A população, enquanto não ouvir ele fazendo menção ao seu nome ou epíteto pelo 
qual será chamado, assim como proferir uma parábola que garanta segurança ou os convença, responderá não. Tão logo ele cite o nome dele, e os convença com provérbios, receberá o sim da população como símbolo de conferir a legitimidade ao novo soberano. Passo de seguida um exemplo desse momento, durante a entronização de Ekuikui IV (MAT, 2004, p. 96).

- Ame Tchicambi Tchasiya Onjamba - (O Unita yanjnili, pokusya yandisiyila vowambo etali figasi peka lya MPLA)! - Sou o Tchicambi deixado pelo elefante (A Unita me deixou no Huambo, hoje estou nas mãos do MPLA).

Resposta: haveko wakemba! - Não és, mentiste.

- Ame kapunila kamoli onanga (ove kwandele ongongo kwakolele ndafigo lolombi vyove vutwe). - Sou o Kapunila que não vê feiticeiros (Você que não sofreu, não és forte).

Resposta: haveko wakemba! - Não és, mentiste.

- Ame Elamba lyomola osoma (Etchi okasi kusoma vosi vakusivaya, katito walinga vosi vakuyengumbula - (Sou o cheiro do filho do soba glória no princípio desprezo no fim).

Resposta: haveko wakemba! - Não és, mentiste

- Ame Ekuikui IV, ya kwãla (Elanga ngongo tchikundyakundya puka kaliliwa lonjila - soma yombala yo Mbalundu). Sou o Ekuikui IV (Um inseto que não é comível pela ave - rei do reino do Mbalundo)

Resposta: We welekete we we we...otcho, wamba ondaka! - We welekete we we we... Sim we we we, é isto mesmo, lançou a palavra certa.

Este gesto exterioriza o consentimento da população em relação à figura do futuro soma inene como legítimo soberano e representante dos mesmos. As respostas "sim e não" são consequências do anúncio ou esclarecimento prévio que a corte faz à população sobre a personalidade escolhida para dirigir o reino. Portanto, a população é devidamente ensaiada ou preparada para esse momento único, o momento em que esta é solicitada a conferir a legitimidade ao futuro soberano.

\section{c) Legitimidade conferida pelo Estado}

É o último agente a intervir publicamente nesse processo. O Estado, ciente do papel de representatividade estatal que as autoridades consuetudinárias exercem em suas localidades, sente-se na obrigação de reconhecer a legitimidade conferida segundo os princípios consuetudinários e pela população, e solicitar que os mesmos, nos seus afazeres costumeiros, não entrem em choque com a constituição 
vigente da República de Angola, e os artigos $223^{\circ}, 224^{\circ}$ e $225^{\circ}$ da mesma (2010) fazem menção a esse reconhecimento, representatividade e regimento. Ou seja, a C.R.A, no seu Artigo 223, ponto 1, diz que "o Estado reconhece o estatuto, o papel e as funções das instituições do poder tradicional constituídas de acordo com o direito consuetudinário e que não contrariam a Constituição" (IBIDEM, 2010, p. 79); no seu Artigo $224^{\circ}$, diz que "as autoridades tradicionais são entidades que personificam e exercem o poder no seio da respetiva organização político-comunitária tradicional, de acordo com os valores e normas consuetudinários e no respeito pela Constituição e pela lei” (IBIDEM, 2010, p. 79); e no Artigo 225을 diz que

as atribuições, competência, organização, regime de controlo, da responsabilidade e do património das instituições do poder tradicional, as relações institucionais destas com os órgãos da administração local do Estado e da administração autárquica, bem como a tipologia das autoridades tradicionais, são regulados por lei. (IBIDEM, 2010, p. 79).

Nessa senda, o Estado nacional angolano confere a legitimidade ao soma inene, a partir do momento que o concebe e o reconhece como uma figura soberana consuetudinária, e deste ponto de vista, a legitimidade estatal também poderia ser considerada como "atribuída".

A respeito disto, Orre diz que essas autoridades consuetudinárias

gozam também de uma legitimidade que lhes é outorgada enquanto intermediários reconhecidos pelo Estado e, portanto, - em termos weberianos - da autoridade legal-racional que a instrumentalização administrativa lhes confere. (ORRE, 2009, p. 146).

Para terminar essa análise sobre a questão da legitimidade, devo dizer que o soma inene, para que se sinta e se conceba por parte de outros agentes sociais, culturais e, sobretudo, políticos como uma figura soberana, sagrada e legítima, deve merecer esses três consentimentos, fundamentalmente o consuetudinário e o populacional. Acredita-se que é a partir do parecer desses que se lhe atribui, entre outros, poderes sobrenaturais que o permitirão entrar em contato com os espíritos dos antepassados do Mbalundo, que, segundo a crença local, constituem a fonte de respostas aos mais variados problemas que eventualmente surgirem no seio da população. Como postulou Florêncio,

en palabras de Georges Balandier (1987, p. 105), "los soberanos son los parientes, los homólogos o los mediadores de los dioses”. En este sentido, la sacralización del 
poder político del soberano constituye un aspecto importante de su legitimidad, pues la continuidad reproductiva de los hombres y de las cosas se garantiza gracias a su lugar de representación y mediación con sus divinidades, que el soberano ocupa y maneja. (BALANDIER apud FLORÊNCIO, 2009, p. 176).

\section{A autoridade e hierarquia no reino}

A questão da autoridade no reino está vinculada com a da sucessão e legitimidade, pois entendo que ao sucessor, uma vez legitimado, é atribuído poder e, se for para o cargo de soma inene, passará a responder como soberano ou autoridade máxima do reino e da etnia ovimbundu.

Dessa feita, no reino podemos encontrar as autoridades consuetudinárias divididas em soma inene, olosoma, olosoma vionduko e olosekulo, e as mesmas podem ser apresentadas em duas estratificações, uma segundo a consideração ou estratificação do Estado nacional angolano atual (ver estratificação A), e outra segundo a estratificação local que se faz levando em consideração a aproximação e o grau de influência e responsabilidade que cada um dos grupos mantém e tem em relação à autoridade máxima no cumprimento das mais variadas missões pelas quais todas existem (ver estratificação B).

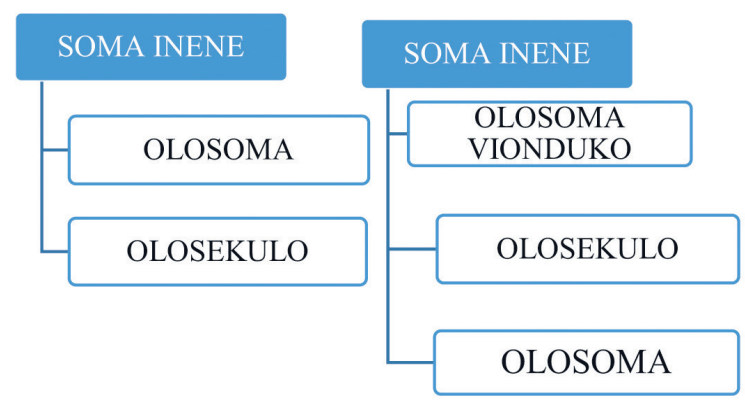

Figura 15.6 - Estratificação A e estratificacação B

A estratificação A, constituída por três grupos, apresenta o soma inene como a autoridade máxima das autoridades do reino; ao meio, os olosoma, que é o conjunto de autoridades consuetudinárias que representam o soberano nas mais variadas regiões que compõem o reino, sendo portanto considerados também au- 
toridades máximas do ponto de vista consuetudinário nessas localidades; na base, aparecem os olosekulo, que respondem como intermediários entre a população e o Estado, ou seja, entre o poder jurídico-administrativo e o poder consuetudinário. São as únicas com direito a uma remuneração mensal garantida pelo Estado nacional angolano atual. Segundo Ekuikui V, "eu recebo das mãos do nosso Estado 21 mil Kwanzas por mês, os sobas e os sekulos também recebem, mas estes sobas de nome não recebem subsídios" (entrevista concedida em sua casa / Março de 2015).

A estratificação B também apresenta como soberano das autoridades do reino o soma inene; a seguir a ele, aparecem os olossoma vionduco, que, no seu todo, constituem a chamada corte do soma inene. São o sustentáculo do soma inene, pois este se sente impossibilitado em agir, decidir ou resolver qualquer problema na ausência desses, ou pelo menos sem o consentimento dos mesmos ou parte desses. Porém, estas autoridades são apenas reconhecidas oficialmente segundo o direito ou princípios consuetudinários, eis a razão de não serem diretamente recompensados subsidiariamente pelo Estado nacional angolano atual, mas, sim, segundo políticas internas do reino. ${ }^{73}$ É o grupo de autoridades consuetudinárias mais próximo ao soma inene. Posteriormente, aparecem os olosekulo, já referenciados na estratificação anterior, e com as mesmas funções têm a representatividade garantida na corte do soma inene. Na base, estão os olosoma, pois apesar de serem os representantes do soma inene, como dissemos anteriormente, os mesmos, genericamente falando, mantêm um contato direto com o soma inene quando são convocados para prestações de contas, ou na eventualidade de se sentirem impossibilitados em dar respostas a um determinado problema, procurando para o efeito um auxílio por parte do soma inene e dos losoma vionduko. Nas duas estratificações, o soma inene aparece no topo, razão para se pensar que o sistema de governo no reino é monárquico. Trata-se de um sistema de governo que julgo caracterizar boa parte das instituições consuetudinárias africanas, pois no topo de cada estrutura política encontra-se sempre um chefe, uma autoridade máxima ou um soberano, que trabalha em sintonia com os outros constituintes da estrutura, podendo passar suas prerrogativas a estes para que o representem quando necessário.

Todavia, entendo que essa hierarquia espelhada não deve ser vista como fundamento ideal para interpretar o poder no reino, pois, se assim for, a opera-

73 Os losoma vionduko são remunerados a partir do dinheiro que se arrecada dos visitantes que se deslocam à ombala, dos julgamentos, das ofertas singulares ao reino e de toda atividade remunerada que o soma inene e os mesmos realizarem em prol do reino. Esse valor no final do mês é somado e dividido por 35 e o resultado será a recompensa em dinheiro de cada um dos membros da corte. 
cionalidade do poder passaria a ser pensada exclusivamente na verticalidade. Porém, não defendo que se olhe somente assim para o poder no reino, pois a minha perspetiva é que o mesmo seja analisado na horizontalidade, por ser um indicador que opera na base de consenso ou dentro da lógica de reciprocidade. A hierarquia aqui deve ser vista como o indicador relacional ou denominador comum entre os grupos que constituem as autoridades consuetudinárias do reino. De acordo com Arendt,

a relação autoritária entre o que manda e o que obedece não se assenta nem na razão comum nem no poder do que manda; o que eles possuem em comum é a própria hierarquia, cujo direito e legitimidade ambos reconhecem, e na qual ambos têm seu lugar estável predeterminado (ARENDT, 1992, p. 129).

\section{O soma inene e a sua corte}

Ao terminar a descrição anterior, procurei demonstrar que o poder na estrutura política do reino do Mbalundo é visto como algo que se exerce no coletivo, em que cada parte integrante se sente obrigada a desempenhar seu papel e a reconhecer e respeitar as funções de outrem, para que desste modo se garanta tal operacionalidade. É por essa razão que a descentralização do poder é entendida como um fator que contribui para que o reino fundamente a sua existência como uma instituição que trabalha para dar respostas aos problemas de âmbito consuetudinário e jurídico-administrativo dos ovimbundu. Portanto, a descrição ${ }^{74}$ seguinte visa demonstrar esta descentralização do poder no reino, que, entre outras, produz como consequência uma relação de dependência entre as autoridades consuetudinárias do reino. Para o efeito, tomarei como exemplo dessa problemática a descentralização desse poder na ombala yo Mbalundo, onde as autoridades analíticas serão o soma inene e os losoma vionduko. E, no final desta descrição, espero deixar claro que, a exemplo de outras estruturas políticas consuetudinárias africanas, no reino do Mbalundo também se pode identificar fundamentos ou caracteres de uma teocracia democrática, como sustentou Senghor, pois, de acordo com o autor, "cá e lá, deparamos com um monarca constitucional que não pode tomar nenhuma decisão sem estar conforme com um senado" (SENGHOR apud ALTUNA, 2014, p. 104). Ou seja, a ideia de que até o soberano hierárquico depende dos losoma vionduko.O soma inene é a figura soberana do reino e da etnia

74 Essa descrição será feita de acordo com as entrevistas feitas com o soma inene Francisco Armindo Kalupeteka (em 23 de março de 2015), o usonehi Fernando Hosi e o sekulo Domingos Manuel Tchimbulo (aos 19 de março de 2015). Algumas ideias as desenvolvi inspirando-me em MAT (2004, p. 96-98). 
ovimbundu. Ele é comumente entendido como uma figura poderosa e reguladora da ordem no seio da comunidade, daí as suas funções jurídicas e legislativas. É um agente que exerce o controle e comunicação com o universo mágico, pois acredita-se que o mesmo possua capacidades para manusear as forças do oculto e intermediar ou estabelecer a comunicação entre dois mundos - o dos vivos, onde residimos, e o dos mortos, onde residem os espíritos de seus antepassados - com o escopo fundamental de supostamente garantir o bem comum.

Poderia descrevê-lo ainda como a figura responsável pela união de todos os tecidos sociais da etnia ovimbundu, pois, de acordo com Vansina, "um rei é o ‘fio' que cose a multidão” (VANSINA apud SILVA, 1994, p. 122). Essa perceção do soma inene como um dos promotores da coesão social, como regulador e fundamentalmente como intermediário de mundos, dialoga com o que se subentende de um rei em outros pontos geográficos. A exemplo disso, Granet diz que a escrita chinesa conservou os traços dessa filosofia, pois que, para eles, "a palavra rei (wang) escreve-se com um sinal composto por três traços horizontais, que representam, segundo dizem os etimologistas, o céu, o homem e a terra, unidos a meio por um traço vertical, porque o papel do rei é unir" (GRANET apud SILVA, 1994, p. 122). Ideia similar foi defendida pelo antropólogo Lévi-Strauss no seu estudo sobre a problemática da reciprocidade na chefia entre os bandos nambikwara (comunidade caçadora e coletora): segundo ele, "o termo uilikandé (chefe) parece querer dizer "o que une" ou "o que liga" (LÉVIS-STRAUSS apud SILVA, 1994, p. 122).

Do ponto de vista administrativo, o soma inene tem a missão de coordenar as tarefas que a administração municipal incumbe para as autoridades consuetudinárias do reino, como, por exemplo, as de mobilização das populações para as campanhas relacionadas com a saúde, nomeadamente as de vacinação, de esclarecimento da população para respeitar e introduzir hábitos de higiene, e a intermediação entre as populações e os centros de saúde e outras instituições.

Por essa razão, cabe ao soma inene estabelecer relações com outras autoridades através de políticas coletivamente pensadas, aconselhar e coordenar seus membros e todas as atividades desenvolvidas no reino.

No exercício de suas funções, o soma inene conta com o suporte de 35 autoridades que constituem a sua corte, e cada uma tem uma missão específica diante das mais variadas situações, como descreverei a seguir.

\section{Epalanga}

É o soma inene adjunto e deve pertencer também a uma das linhagens dos reis do Mbalundo. Porém, nesse momento, o reino está sem um representante para essa categoria, o que não quer dizer que não existam substitutos por direito, caso seja necessário. 


\section{Inakulu}

É a rainha e, na atualidade, a única autoridade de gênero feminino pertencente à corte. Ela é entronizada em simultâneo com o soma inene, e, entre outras, responsabiliza-se pelas situações de âmbito feminino que, por tabus, apenas ela deve reportar ao seu esposo, ou aos seus parceiros, se necessário for. Ela desenvolve mecanismos que visam coordenar as atividades das associações de caráter feminino no reino, incentiva as mulheres do reino, fundamentalmente as da ombala, a pautarem por comportamentos exemplares, com maior realce na adesão aos estudos, pois só assim inverterão definitivamente o papel de doméstica que genericamente se lhes atribui.

Poderia dizer que a poligamia é um fato no reino, basta observar que existem nomes devidamente preparados para o conjunto de mulheres que eventualmente um rei possa ter, nomes que ao mesmo tempo espelham uma hierarquia entre elas. Assim sendo, a inakulu seria a primeira esposa e, por este fato, a rainha. No caso de existirem outras, teriam, entre outros, os seguintes nomes: sia (segunda esposa); nangandala (terceira esposa); mbavela (quarta esposa), tchiwotchepembe (quinta esposa).

\section{Usonehi}

Este desempenha as funções de secretário. É o canal que a população tem para reportar os seus problemas para a ombala, a fim de serem resolvidos pelo soma inene e sua corte. O onjango ${ }^{75}$ externo direito (ver Figura 13.6) é o seu gabinete; é nele que recebe os munícipes solicitantes. Anotados os problemas, terá a missão de os transmitir em primeira instância ao soma inene, que, na presença deste e dependendo da natureza do problema, agendam o dia para resolvê-lo. Desde 1999 até a atualidade, este cargo é desempenhado pelo soma Fernando Hosi, parente paterno de Ekuikui V. Vale dizer, ainda, que o mesmo, na impossibilidade do soma inene ou do epalanga fazerem-se presentes para a resolução de qualquer problema devidamente agendado, tem a prerrogativa de os representar.

75 Onjango: alpendre construído com paus e coberto de capim; os paus das paredes ficam ligeiramente curtos, separados uns dos outros de forma que todos que nele não tenham lugar continuem a ver e a ouvir o que se passa lá dentro - (local onde se discutem problemas da comunidade, os jovens adquirem conhecimentos da história e dos costumes). (MAT, 2004, p. 59). 


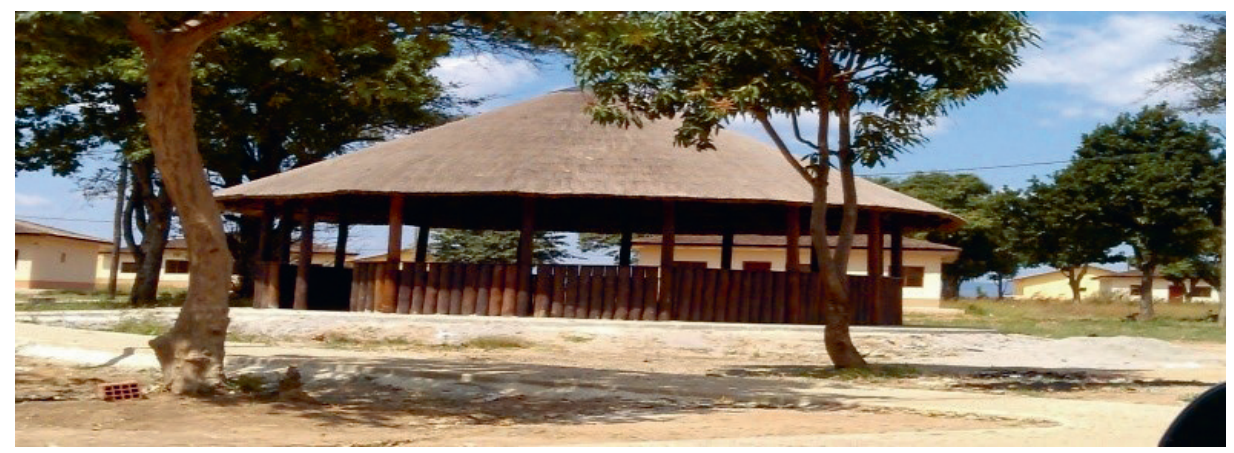

Figura 15.7 - Onjango externo direito

\section{Soma Ngambole}

Figura que entroniza o soberano e responde como conselheiro da corte. Assim sendo, o soma inene, bem como os losoma vionduko, sempre que estiverem diante de algumas situações de caráter particular ou coletivo, como conflitos no lar ou desentendimento entre colegas, recorrem a ele. Mesmo durante os julgamentos na ombala, ele intervém aconselhando sempre que possível os membros do tribunal, os réus, bem como a população assistente.

\section{Soma Muekalia}

Membro da corte com a missão de entronizar também o soma inene, a exemplo do soma ngambole. O indivíduo a quem se atribuir esse cargo deve ter uma personalidade de alguém acolhedor e que, entre outras, adore oferecer ou partilhar e servir, e, por essas características, ele é considerado a mãe dos losoma. É auxiliado por dois constituintes da corte, que a seguir serão mencionados.

\section{Soma Chikaka}

Adjunto do soma muekalia.

\section{Soma Chikukulo}

Membro da corte com a missão de auxiliar os losoma muekalia e ngambole.

\section{Soma Siasoma}

É o responsável pela segurança e proteção do soma inene. É o segurança secreto da corte, e que estimula várias vezes conversas a desfavor do soma inene ou 
sobre o modo de intervenção cultural, social e econômica da corte, para testar ou perceber o nível de confiança dos seus serviços diante da população. É também o único da corte responsável pela otchalo (cadeira) do soma inene.

\section{Soma Kasoma}

É o responsável pelo estado de saúde do soma inene e, por essa razão, é o único que diariamente e pelas manhãs deve se deslocar à moradia do soberano, e reportar em seguida o estado do soberano aos seus colegas, pois, a partir disso, saberão se poderão contar ou não com a autoridade máxima em mais uma jornada laboral.

\section{Soma Ndaka}

É o porta-voz ou mensageiro da corte. No interior da ombala, as mensagens ou informações sobre acontecimentos como mortes, reuniões, campanhas de higiene, entre outras, não dependem dos órgãos de comunicação massiva. Logo, cabe a esse indivíduo circular pelo bairro todo e com voz alta passar as mais variadas mensagens aos moradores.

\section{Soma Epango}

Vela pela segurança alimentar do soma inene (nutricionista do soberano). É o canal por onde obrigatoriamente devem passar todas as ofertas alimentares que qualquer um fizer ao soberano. Segundo a realidade local, ninguém, por exemplo, abate um gado bovino e se alimenta da carne sem oferecer parte desta ao soma inene, porém, essa oferta não chega diretamente ao soma inene, deve antes passar pelo soma epango, que analisa o estado dela e decide se a fará chegar ou não às mãos do soma inene.

\section{Soma Kesongo ou Kumandandi}

É o guia do soma inene e da corte. O mesmo escolta as movimentações destes no interior da ombala. O seu gabinete de trabalho é o onjango externo esquerdo, local onde recebe os visitantes, uma vez que qualquer indivíduo que se dirigir para a ombala em busca dos serviços prestados por eles deve antes passar pelo seu gabinete, a fim de trocarem as primeiras impressões, para depois serem encaminhados ao usonehi. 


\section{Soma Chilala}

A higienização do atambo (santuário tradicional) e dos akokoto (cemitério dos soberanos) é de inteira responsabilidade deste e do seu adjunto.

\section{Soma Chikola}

É o adjunto do soma chilala, e ambos responsabilizam-se pela higiene do santuário tradicional e do cemitério dos soberanos.

\section{Soma Henjengo}

É o agitador, catalisador ou atiçador. Tem a função de fazer cumprir as orientações do soma inene, relembrando sempre que possível que o reino tem como soberano uma só figura, e que as decisões ou orientações que o mesmo emanar em nome da corte devem obrigatoriamente ser cumpridas, sob pena de passar por sanções.

\section{Soma Kalufele}

É o adjunto ou colaborador do soma henjengo.

\section{Soma Chiwale}

É o responsável pela indumentária ou vestuário do soma inene. Ou seja, é o único que cuida do aspecto visual do soberano. Qualquer falha nesse pormenor, como roupa suja, camisa mal abotoada ou gravata mal posta, e as responsabilidades serão todas atribuídas a esse soma.

\section{Soma Kalei}

É o membro da corte com a função específica de servir a alimentação ou bebidas ao soma inene.

\section{Soma Kesenje}

Autoridade responsável por proporcionar momentos de lazer ou recreativos ao soma inene, e é ao mesmo tempo o conselheiro direto dele e o juiz do tribunal da corte. 


\section{Soma Lumbo}

Responsável pela cerca da ombala e dos akokoto.

\section{Soma Lombundi}

É a figura da corte que desempenha as funções de porteiro. Ou seja, tem a missão de abrir e fechar as entradas e saídas da ombala.

\section{Soma Ndalu}

Integrante da corte, responsável pelo fogo e por segurar o animal durante o abate, bem como pelo cuidado do sangue deste.

\section{Soma Chitonga}

Figura que acende o fogo no onjango.

\section{Soma Sipata}

É o único da corte que transporta o símbolo de poder do soma inene, isto é, a espada, e é por isso também considerado o guarda-costas do soberano.

\section{Soma Lumbungululu}

É caracterizado como o brilho da ombala, é a estrela da ombala, é o responsável pelo brilho ou iluminação da ombala.

\section{Soma Sindako}

É o responsável em manter inviolável o reino diante de qualquer situação, e em levar o mesmo à conquista de outros espaços se necessário for. Durante as movimentações internas, ele deve ocupar sempre a última posição.

\section{Soma Tembuasoma}

O soma inene e os losoma hoje se alimentam da comida feita pelas suas esposas também, porém, em tempos áureos, evitava-se isso. Logo, este soma era o cozinheiro do soma inene ou da ombala. A ele também se incumbe a missão de cuidar das esposas dos losoma. 


\section{Soma Sunguahanga}

Adjunto do soma tembuasoma, desempenha igualmente as funções de mobilizador de massas.

\section{Soma Nuñulu (nunhulu)}

É filho primogênito do soma inene.

\section{Soma Ukuepandela}

É o responsável pelo içar e o arrear da bandeira na ombala, e que é usada como catavento.

\section{Soma Katumua}

É o batuqueiro ou tamborista da corte e o responsável pelos demais indivíduos que manuseiam esse instrumento e têm a missão de animar os encontros na ombala, bem como desejar, com o som agradável que produz ou produzem, boas-vindas aos visitantes.

\section{Soma Uchilã}

É o dançarino da corte e dança sempre com uma cauda de boi, que usa para expulsar as moscas que estiverem em direção ou pousarem no soma inene. E, sempre que o soma inene estiver dançando, o mesmo deve como maestro guiar os movimentos do soberano.

\section{Soma Chikakula}

Desde a fundação do reino, o abate de determinados animais tem um valor simbólico, fundamentalmente durante a entronização. Logo, esse soma é o responsável pelo abate de tais animais e pelas queimadas que se efetuam durante a caça e higienização da ombala.

\section{Soma Kapitango}

É o responsável por garantir a proteção física da ombala. 


\section{Sekulo}

É o chefe da ombala, figura que tem a missão de reportar para a administração municipal os dados qualitativos e quantitativos ou demográficos da população residente na ombala. Ele não necessariamente deve pertencer a uma das linhagens dos reis, mas, sim, deve ser uma figura adulta, que tenha um comportamento exemplar e que se mostre um exímio conhecedor da população local.

Existem ainda dois grupos de indivíduos não pertencentes à corte e que prestam serviços na casa do soma inene. O primeiro é o acombi, composto por indivíduos que se responsabilizam pela limpeza, e o segundo é o olonana vie elombo, composto por um conjunto de mulheres que prestam serviços domésticos, auxiliando a inakulu.

\section{Considerações finais}

À guisa de conclusão, a presente análise procurou mostrar que, apesar de nos últimos tempos servirem-se mais da norma matrilinear no processo sucessório, é necessário que se reconheça, também, que em determinados momentos da história do reino é patente a perspetiva patrilinear. A consanguinidade foi e continua sendo o indicador central nessa tradição sucessória. Porém, devo dizer, também, que indicadores como a procedência da linhagem residencial/familiar, a observância dos conhecimentos locais, dos seus hábitos e costumes, o espírito de liderança e a concordância da voz do povo são também preponderantes ou considerados nesse processo.

O soma inene, uma vez legitimado, passa a responder como autoridade máxima do reino e, por conseguinte, a se beneficiar do monopólio de decisão. Mas este fato não deve de modo algum levar a concebê-lo como o detentor do poder, pois o poder não é monopólio de um ou de uns, mas, sim, algo que opera dentro de uma lógica de interdependência. E essa forma de pensar também caracteriza os losoma vionduko, uma vez que cada um se sente parte decisiva no sistema. Enfim, é reconhecido o lugar do soberano, porém isso não faz com que os demais sejam meros passivos. Como postulou Gramsci, "os membros de uma classe subordinada podem ser críticos e estar conscientes de sua posição de subordinação" (GRAMSCI apud CALDEIRA, 1989).

Finalmente, interpretando a estrutura do poder político da ombala apresentado nessa análise, pode-se concluir que, embora o soma inene detenha o monopólio de decisão, ele é em simultâneo o indivíduo mais dependente de todos que constituem a sua corte. Ou seja, a estrutura política descrita demonstra que, para todos os efeitos, o poder é descentralizado, uma estrutura onde se reconhece a existência de uma figura soberana e que, ao mesmo tempo, esse soberano nada se- 
ria sem o contributo dos seus membros mais diretos, no caso os losoma vionduko. Portanto, e diante disso, me arriscaria mais uma vez em concluir que o soberano étnico é em simultâneo a figura mais dependente do conjunto de autoridades do reino do Mbalundo. Aliás, Hannah Arendt postulou que

o rei, que não é mais do que um indivíduo solitário, depende muito mais do apoio geral da sociedade do que em qualquer outra forma de governo [...], o poder do governo, depende de números; ele reside na proporção do número ao qual é associado. (ARENDT, 2014, p. 58).

\section{Referências}

ALTUNA, R. R. A. P. Cultura tradicional Bantu. 2. ed. Portugal: Paulinas Editora: 2014.

APPADURAI, A. Soberania sem territorialidade: notas para uma geografia pós-colonial. Novos Estudos Cebrap, São Paulo, n. 49, p. 7-32, 1997.

ARENDT, H. Entre o passado e o futuro: que é a autoridade? 3. ed. São Paulo: Perspectiva, 1992.

. Sobre a violência. 5. ed. Rio de Janeiro: Civilização Brasileira, 2014.

BURGUIÉRE, A. et al. História da família: o choque das modernidades, Ásia, África e Europa. Lisboa: Terramar, 1998.

CALDEIRA, T. P. R. Antropologia e poder: uma resenha de etnografias americanas recentes. BIB, Rio de Janeiro, n. 27, p. 3-50, 1989.

CARDOSO, V. Z. Diálogos transversais em antropologia. Florianópolis: PPGAS/UFSC, 2008.

CLIFFORD, J.; GONÇALVES, J. R. S. (Org.). A experiência etnográfica: antropologia e literatura no século XX. 2. ed. Rio de Janeiro: UFRJ, 2002.

FEIJÓ, C. M. S. et al. (Coord.). Constituição da república de Angola. Luanda, 2010. Disponível em <http://www.governo.gov.ao/Arquivos/Constituicao da Republica de Angola.pdf $>$. Acesso em: 28 ago. 2015.

FLORÊNCIO, F. Autoridades tradicionais, Estado e partidos políticos, no município do Bailundo: uma arena política plena de ambiguidades e contradições. Academia, 2015. Disponível em <https://www.academia.edu/3750020/S/A >. Acesso em: 20 set. 2015. . Um reino, dos reyes. Diferentes legitimidades em Bailundo (Angola). Revista CIDOB d'Afers Internacionals, Barcelona, n. 87, p. 167-189, out. 2009. 
GOULART, M. Não há verdades africanas: a incorporação das autoridades tradicionais na administração pública dos PALOP. Observatório dos Países de Lingua Oficial Portuguesa, Rio de Janeiro, 2012.

KI-ZERBO, J. Metodologia e pré-história africana. Tradução do Centro de Estudo Afro-Brasileiro da Universidade Federal de São Carlos. 3. ed. Brasília, DF: Unesco, 2011.

MATTA, R. Relativizando: uma introdução à antropologia social. Petrópolis: Vozes, 1981.

MAT - MINISTÉRIO DA ADMINISTRAÇÃO DO TERRITÓRIO. $1^{\circ}$ Encontro Sobre a Autoridade Tradicional em Angola. Luanda: Nzila, 2004.

OLIVEIRA, R. C. O trabalho do antropólogo. 2. ed. Brasília, DF: São Paulo Editora, Unesp, 2000.

ORRE, A. Fantoches e cavalos de Tróia? Instrumentalização das autoridades tradicionais em Angola e Moçambique. Lisboa: Cadernos de Estudos Africanos, 2009.

SILVA, J. C. G. Identidade Roubada: ensaios de antropologia social. Lisboa: Gradiva, 1994.

\section{Entrevistados}

Armindo Francisco Kalupeteka, 41 anos, soma inene do reino.

Fernando Hosi, de 59 anos de idade, usonehi ou secretário da corte.

Domingos Manuel Tchimbulo, 57 anos, sekulo da ombala.

Irineu Cândido Leonardo Sacaála, 54 anos, administrador do município do Bailundo. 